then the name of the pathogen and lastly its geographical distribution within the United States.

Chapter 5 is thus a reference list for supplying the first clues to the identity of a disease on any particular plant. A person interested, for example, in a leafspotting disease first collects in Chapter 5 the names of all the pathogens causing this type of trouble on the selected host plant. He then turns to Chapter 4, where under the heading "Leaf Spots" will be found all the leaf-spotting pathogens with, for any particular hest, a detailed description of symptoms and the control measures required.

The system does not take long to understand and does not require the reader to be specially trained in plant pathology. In any event, it does not pretend to provide for accurate diagnoses of any and every disease, but claims to be a useful working guide to assist gardeners, nurserymen, seedsmen and the like in their daily work.

The suthor is well qualified to write a book of this kind, for she served for many years as plant pathologist on university and experimental station staffs in the United States. She is now doing advisory work in a private capacity as consultant and has written several books on gardening matters. This one claims to be a book of reference for gardeners; but it is much more than that, for it can be of use to scientific workers and should find a place on their bookshelves. The fact that it is written for horticulturists in the United States need not deter plant pathologists in Great Britain from reading it with interest and with profit.

There is no book comparable with it in Britainthere are more comprehensive ones suitable for the academic study of plant pathology, but none which supplies the working horticulturist with this kind of information in such quantity and in such understandable form.

Dr. Westcott has dedicated the book to her old teacher, the late Prof. Whetzel, of Cornell University; and es one who knew him I consider this volume a worthy tribute to his memory. The publisher and printer are to be congratulated on the quality of the paper and the print.

D. E. GREEN

\section{RESEARCH ON MARRIAGE}

Patterns of Marriage

A Study of Marriage Relationships in the Urban Working Classes. By Dr. Eliot Slater and Moya Woodside. Pp. 311. (London: Cassell and Co., Ltd., 1951.) 17s. 6d. net.

WARS often provide opportunities for research W that would not otherwise have been undertaken, and this book is an example of this. During the Second World War millions of men were seized from their homes, herded together and subjected to strains and stresses which may have differed in intensity but were of much the same character. The two authors of this book, one an expert in psychological medicine and the other a research psychiatric social worker, took the opportunity of investigating why some of these men broke down under the strain of war service while others managed to tolerate it. To what extent, they asked themselves, is the incidence of a neurosis determined by heredity and to what extent by environment? As their research proceeded, other interesting questions concerning marriage had to be answered. What sort of people do different types of men and women choose as partners ? Do neurotics tend to marry neurotics, and, if they do so, are these marriages associated with a high or a low fertility-rate? As a result of this joint war-time inquiry much information of great value to the psychiatrist and to the social worker was obtained. Home conditions and marriage relationships became of paramount importance in this research, so that this book, in which are recorded the results of the inquiry, bears the sub-title of "A Study of Marriage Relationships in the Urban Working Classes".

It is interesting to learn that among the lower classes the chief motive for marrying is not sexual attraction or romantic love, but the desire to acquire a home. "I wanted a wife and was ready to marry anybody" ; "it's somewhere to come home to"; "I thought I'd like a home of my own". Such were the answers generally given to the question, "Why did you marry?" ; and, as everybody now knows, it was only the fortunate few among these ardent seekers of a home who were destined to find one in the years to come. Small wonder, therefore, that when the hope which originally brought the couple together never materialized, many of them drifted apart.

The conclusions reached by these two research workers are based on the answers returned to their questioning of two hundred married couples. The husbands in these couples were Londoners serving in the Army, Navy or Air Force, who had been admitted to a war-emergency hospital situated not far from the Metropolis. Only Londoners were selected for the inquiry, in order to facilitate subsequent visits to their homes and interviews with their wives. Half these men were patients in the medical or surgical wards of the hospital, and the other half were receiving psychiatric treatment there. This allowed of a comparison being made between psychiatrically normal husbands and those that, psychiatrically speaking, were unsound. It is possible to give only a few of the results of this research. One point that soon became obvious was that like tended to marry like- the intelligent man, the intelligent woman; the neurotic, the neurotic. Sexual attraction played only a minor part in drawing two people together. Among the psychiatrically sound couples 45 per cent claimed to be happily married, 36 per cent considered their marriage satisfactory, 10 per cent unsatisfactory and 9 per cent admitted to being positively unhappy. In the neurotic group happiness or satisfaction in marriage was less frequent. It is clear also from the answers given that children ranked highest in bringing about marital happiness and that other factors, in diminishing order of importance, were as follows : "clerical rating of personality, economic status, intelligence, orgasm adequacy of the female, premarital chastity, good looks, stature, rating of personality by test, similarities between husband and wife and test responses". Frequency of intercourse and youth bore no relationship at all to marital happiness.

"Patterns of Marriage" has appeared at a very opportune moment on the very eve of a Royal Commission inquiry into divorce, and it contains informa. tion which should be of the very greatest value to members of this Commission. If any criticism has to be made of the book, it is that the valuable information it contains could, by a little more knowledge of the art of writing, have been presented in a much clearer and more interesting way. But that is a criticism that could be mado of fifty per cent of technical works by medical authors.

KENNETH WALKER 